\title{
A critical analysis of the impact of water on the South African campaign in German South West Africa, 1914-1915
}

\author{
Evert Kleynhans*
}

\begin{abstract}
The South African campaign in German South West Africa (GSWA) during the First World War depended largely on the access, availability and control of all water sources in the operational area. The Union Defence Force (UDF) appreciated the strategic nature of water before the invasion of GSWA in 1914, because it was well known that there were no permanent water sources along the routes of advance into the country. Fears about the possibility of German sabotage and poisoning of the available water remained a constant concern for the South African defence planners throughout the campaign, and adequate water supplies that were fit for both human and animal consumption became a strategic military concern. This meant that the Defence Force had to adopt a number of measures to meet the growing demand for water. Boreholes were sunk across the operational area and in addition, fresh water was transported across the Kalahari Desert by motor vehicles and via shipping from Cape Town. To some extent, the provision of safe drinking water dictated the pace of the South African campaign in GSWA.
\end{abstract}

Keywords: First World War; German South West Africa; Union Defence Force; offensive operations; climate and terrain; water.

\section{Opsomming}

Die Suid-Afrikaanse veldtog in Duits Suidwes-Afrika (DSWA) tydens die Eerste Wêreldoorlog was grotendeels beïnvloed deur toegang tot, die beskikbaarheid van, en die beheer oor alle waterbronne in die operasionele gebied. Die Unieverdedigingsmag (UVM) het die strategiese belang van beskikbare water besef, nog voor die inval van DSWA in 1914, veral omdat dit bekend was dat daar geen standhoudende waterbronne langs die verskeie invalroetes was nie. Die Suid-Afrikaanse militêre

* Evert Kleynhans, MMil (Stell), is a candidate in the PhD (Mil) programme of the Department of Military History, Faculty of Military Science, at Stellenbosch University. His research interests include South African participation in both the World Wars; the influence of weather and terrain on warfare; the Axis and Allied maritime operations in the southern oceans; and the wider milieu of war and society in southern Africa. Contact the author at evertkleyn@gmail.com

How to cite this article: E. Kleynhans, "A critical analysis of the impact of water on the South African Campaign in German South West Africa, 1914-1916, Historia 61, 2, November 2016, pp 29-53. http://dx.doi.org/10.17159/2309-8392/2016/v61n2a2

Copyright: (C) The Author(s). Published under a Creative Commons Attribution Licence. 
beplanners het deurgaans gevrees dat die Duitse magte die beskikbare waterbronne óf sou saboteer óf sou vergiftig. Dus het die beskikbaarheid van voldoende water voorrade, vir gebruik deur mens en dier, van strategiese militêre belang geword. Die weermag moes daarom van 'n aantal metodes gebruik maak om die groot aanvraag na water te bevredig. ' $n$ Aantal boorgate is gesink in die operasionele gebied, en vars water is soms selfs per voertuig oor die Kalahari-woestyn aangery of vanaf Kaapstad verskeep. Die verskaffing van veilige drinkwater het sodoende die pas van die SuidAfrikaanse veldtog in DSWA bepaal.

Sleutelwoorde: Eerste Wêreldoorlog; Duits Suidwes-Afrika; Unieverdedigingsmag; offensiewe operasies; klimaat en terrein; water.

\section{Introduction}

There is an ever-present relationship between warfare and the environment. Throughout history, the essential elements of geography (weather, climate, terrain, soil and vegetation) have served as decisive factors in the conduct and outcome of military operations at the strategic, operational and tactical levels of war. ${ }^{1}$ In every area of military operations a number of geographic characteristics unique to that physical area interact with one another to produce a distinctive military operating environment. This operational environment comprises a number of important planning considerations, of which the key elements are the particular location, climate, terrain structure, cultural factors, and observation and concealment. ${ }^{2}$ These considerations provide a useful tool for analysis when studying the historical impact of climate and terrain on warfare.

The centennial commemoration of the First World War has generated renewed interest in South Africa and the involvement of the UDF in this global conflict. Despite a definite resurgence in First World War studies, the major historiographical works on the First World War remain rather conservative in their approach and generally speaking can be termed "drum and trumpet" or campaign histories. ${ }^{3}$ This applies to many of the works which focus on the African campaigns of the war, especially the South African campaign in GSWA. Although numerous books

1. H.A. Winters, et al, Battling the Elements: Weather and Terrain in the Conduct of War (Johns Hopkins University Press, Maryland, 1998), p 1; and H.A.P. Smit and H.S. Janse van Rensburg, "Success and Failure along the Modder River during the Anglo-Boer War: The Influence of Terrain”, Scientia Militaria, 42, 4 (2014), p 118.

2. M.W. Corson, "Operation Iraqi Freedom: Geographical Considerations for Desert Warfare", in E.J. Palka and F.A. Galgano (eds), Military Geography: From Peace to War (McGraw-Hill, Boston, 2005), pp 155-156; J.A. Jacobs, H.S. Janse van Rensburg and H.A.P. Smit, "Military Geography in South Africa at the Dawn of the 21st Century", South African Geographical Journal, 84, 2 (2002), pp 195-196.

3. J. Black, Rethinking Military History (Routledge, London, 2004), pp 26-59. 
have appeared on this campaign, ${ }^{4}$ only a few prominent writers and historians have consulted the available military archival material which focuses on the South African campaign in this former German colony. These documents are readily available at the Department of Defence Documentation Centre (Military Archives) in Pretoria. Despite this, the majority of writers and historians, both amateur and professional, have resorted to simply rephrasing and re-circulating ideas and concepts emanating in the first instance from the official histories of the 1920s and 1930s. Perhaps it is this undue reliance on previously published material which has led to the general apathy for new archival research. This is particularly the case for the latest works which have appeared on this campaign.

The impact of climate and terrain on the campaign in GSWA has received very little scholarly attention. The majority of the publications available on this campaign merely make brief mention of the importance of water during military operations. However, a few of them do indeed discuss the importance of water in greater depth, and these works deserve closer attention.

Ian van der Waag was the first military historian to provide a detailed analysis of how the shortage of water impacted on the campaign in GSWA. He first mentioned the importance of the climate and terrain on warfare in his 2005 chapter, "Water and Ecology of Warfare in Southern Africa", a chapter in African Water Histories: Transdisciplinary Discourses. ${ }^{5}$ Here he argues convincingly that historically, most of

4. These books include, but are not limited to: A. Sampson, World War I in Africa: The Forgotten Conflict among the European Powers (I.B. Taurus, London, 2013); G. L'Ange, Urgent Imperial Service: South African Forces in German South West Africa, 1914-1915 (Ashanti Publishing, Rivonia, 1991); D. Williams, Springboks, Troepies and Cadres: Stories of the South African Army, 1912-2012 (Tafelberg, Cape Town, 2012); J.J. Collyer, The Campaign in German South West Africa, 1914-1915 (Government Printer, Pretoria, 1937); H.F. Trew, Botha Treks (Blackie \& Son, Glasgow, 1936); H. Strachan, The First World War in Africa (Oxford University Press, New York, 2007); I. Gleeson, The Unknown Force: Black, Indian and Coloured Soldiers through Two World Wars (Ashanti Publishing, Rivonia, 1994); General Staff, The Union of South African and the Great War, 1914-1918: Official History (Government Printer, Pretoria, 1924); A.M. Grundlingh, Fighting their Own War: South African Blacks and the First World War (Ravan Press, Johannesburg, 1988); B. Nasson, Springboks on the Somme: South Africa and the Great War, 1914-1918 (Penguin, Johannesburg, 2007); B. Nasson, WW1 and the People of South Africa (Tafelberg, Cape Town, 2014); W.S. Rayner and W.W. O'Shaughnessy, How Botha and Smuts Conquered South West Africa (Simpkin, London, 1916); A. Cruise, Louis Botha's War: The Campaign in German South-West Africa, 19141915 (Penguin, Johannesburg, 2015); J. Stejskal, The Horns of the Beast: The Swakop River Campaign and World War I in South-West Africa, 1914-15 (Helion \& Co, Solihull, 2014) and T. Couzens, The Great Silence: From Mushroom Valley to Delville Wood, South African Forces in World War One (Sunday Times Books, Johannesburg, 2014).

5. I.J. Van der Waag, "Water and Ecology of Warfare in Southern Africa", in J.W.N. Tempelhoff (ed.), African Water Histories: Transdisciplinary Discourses (North-West University, Vanderbijlpark, 2005). 
the conflict in southern Africa has been waged around the access to water. Water, he emphasises, created four distinct environments of war and politics in the region. The most important of these, for the purposes of this article, are the arid and semi-arid regions of southern Africa and of course the military operating environment of GSWA comprised both the Kalahari and Namib deserts. Van der Waag also alludes to the importance of water in the GSWA campaign in his article, "The Battle of Sandfontein, 26 September 1914: South African Military Reform and the German South-West Africa Campaign, 1914-1915",6 as well as his book entitled, A Military History of Modern South Africa. ${ }^{7}$ Both these works provide informative, though at times limited, discussion on the importance of water in the planning stage of the invasion; the problems related to provisioning troops and animals with water; and the German attempts to poison the available water sources as they fell back to their lines.

In his MA dissertation, "Manoeuvre Warfare in the South African Campaign in German South West Africa during the First World War", 8 Antonio Garcia also discusses the importance of water during the campaign. He focuses primarily on the South African military operations and the recourse to manoeuvre warfare throughout the campaign, but he does state that the availability of water, and the geographic location of waterholes had a fundamental influence on the conduct of military operations during the campaign - especially from the manoeuvre warfare theory point of view.

In his book A Doctor's Diary in Damaraland, ${ }^{9}$ Henry Walker provides a firsthand account of his experiences as a doctor during the campaign while attached to the Northern Force. He offers a personal reflection on the importance of water, and the impact that its scarcity had on the South African operations as well as on the medical aspects of the campaign. Another MA dissertation, in this instance by Anri Delport, is "Boks and Bullets, Coffins and Crutches", which also provides some comment on the impact of water on the campaign, ${ }^{10}$ as does Phillip Lehmann's article, "Between Waterberg and Sandveld: An Environmental Perspective on the GermanHerero War of 1904."11 Lehmann describes the interplay between warfare and the

6. I.J. Van der Waag, "The Battle of Sandfontein, 26 September 1914: South African Military Reform and the German South-West Africa Campaign, 1914-1915", First World War Studies, 4, 2 (2013).

7. I.J. Van der Waag, A Military History of Modern South Africa (Jonathan Ball, Cape Town, 2015).

8. A. Garcia, "Manoeuvre Warfare in the South African Campaign in German South West Africa during the First World War", MA dissertation, University of South Africa, 2015.

9. H.F.B. Walker, $A$ Doctor's Diary in Damaraland (Edward Arnold, London, 1917).

10. A. Delport, “'Boks and Bullets, Coffins and Crutches': An Exploration of the Body, Mind and Places of 'Springbok' South African Soldiers in the First World War", MA dissertation, Stellenbosch University, 2015.

11. P.N. Lehmann, "Between Waterberg and Sandveld: An Environmental Perspective on the German-Herero War of 1904", in German History, 32, 4 (2014). For more on the German-Herero War see T. Pakenham, The Scramble for Africa, 1876-1912 (Abacus, 
environment using the war as a lens through which to study this interaction. He argues that although the Germans waged environmental warfare against the Herero by denying them access to water after the Battle of the Waterberg, they too suffered from the extreme heat, shortage of water and disease. The author makes it clear that the military operating environment of GSWA was harsh, and the climate and terrain had a distinct influence on military operations.

Apart from the works identified above, there is no critical analysis on the impact of water shortages on the South African campaign in GSWA during the First World War. This article aims to fill the gap by analysing how water influenced UDF operations throughout 1914 and 1915. Furthermore, it explores the poisoning of water supplies by the Germans in an attempt to halt the South African offensives. In doing so, the article uncovers aspects of the South African campaign which have received little or no scholarly attention thus far.

\section{The military operating environment: an appreciation}

During August 1914, the British government requested the Union of South Africa to invade GSWA and capture the harbours of Lüderitzbucht and Swakopmund as well as the wireless stations at Windhoek, Swakopmund and Lüderitzbucht. The continued operation of the wireless stations during the war was a threat to both the British and entente shipping in the southern oceans, because they made communication possible between Berlin and the German warships on the high seas. The British Committee on Imperial Defence (CID) designated its request to the Union as "urgent Imperial service", and on 10 August, South Africa formally agreed to invade GSWA and meet all the required objectives. Parliamentary support for the invasion was granted in September, and South Africa officially entered the war on 14 September $1914 .^{12}$ The staff officers at the Defence Headquarters in Pretoria then had to make hurried plans for the invasion of the German colony. These plans were based on strategic intelligence reports on the colony, which in part focused on the impact of climate and terrain on that particular military operating environment and its projected influence on military operations. ${ }^{13}$

By September 1914, the UDF had defined the military operating environment of GSWA as follows. The political boundaries of the colony were fixed upon distinct

London, 2012); and H. Bley, South-West Africa under German Rule, 1894-1914 (Heinemann Educational Books, London, 1971).

12. Strachan, The First World War in Africa, pp 63-64; and E.P. Kleynhans, "South African Invasion of German South West Africa (Union of South Africa), 1914-1918", in International Encyclopedia of the First World War (Freie Universität, Berlin, 2015), also available online: $\underline{\text { http://encyclopedia.1914-1918- }}$ online.net/regions/Southern Africa

13. Van der Waag, "Water and Ecology of Warfare in Southern Africa", pp 118-120; and F.C. Whitmore, "Terrain Intelligence and Current Military Concepts", American Journal of Science (Bradley Volume), 258A (1960), pp 376-377. 
geographical features which aided in its defence. The Orange and Kunene Rivers formed the southern and northern boundaries of the colony respectivley, and the rugged Atlantic Ocean coastline and desolate expanses of the Kalahari Desert were the western and eastern borders. It was recognised that the terrain adjoining the southern, eastern and western boundaries was marked by inhospitable, waterless, areas devoid of infrastructure and sparsely populated. Consequently, it was a foregone conclusion that a military advance across these regions would be tough. ${ }^{14}$ It was appreciated that the railway lines were the lifeline of the colony, and these were often used to transport water across the vast, waterless stretches of the coastal belt. The railroad extended from Tsumeb in the north to Kalkfontein in the south, with two parallel lines connecting Lüderitzbucht with Seeheim; and Swakopmund with Karibib. ${ }^{15}$

The geographical and climatological considerations of the military operating environment were the most crucial determinants when the South African general staff was planning the campaign. Before the outbreak of the war, GSWA was referred to as a Sandbüchse, or "sandbox", by a German commentator, Eugen Richter. His analogy of the territory was not entirely wrong, as Phillip Lehmann correctly argues. ${ }^{16}$

The South African staff officers were well aware of the climatological considerations that were unique to the neighbouring colony because they had access to valuable British military reports on the territory. These reports provided accurate, up-to-date intelligence on the social, political, military, geographical and climatological conditions in the colony so the military operating environment of GSWA was addressed, as well as the scarcity of water. The reports also listed all the known water sources in the colony. There were also some publications available for the South Africans to consult, including valuable information on how the scarcity of water had impacted on military operations during the German-Herero war of $1904 .{ }^{17}$ Indeed, the South African staff officers were well informed about the obstacles the

14. Van der Waag, "The Battle of Sandfontein", pp 143-144; General Staff, The Union of South Africa and the Great War, pp 10-12; and J.P. van S. Bruwer, South-West Africa: The Disputed Land (Nasionale Boekhandel, Port Elizabeth, 1966), pp 3-8.

15. Van der Waag, A Military History of Modern South Africa, p 95; and Lehmann, "Between Waterberg and Sandveld", p 541.

16. Lehmann, "Between Waterberg and Sandveld", p 537. According to Lehmann, Eugen Richter, who expressed scepticism over the value of Germany's first colony, was the first to use the term Sandbüchse. See K. Herrfurth, Fürst Bismarck und die Kolonialpolitik (E. Trewendt's Nachfolger, Berlin, 1909).

17. The (UK) National Archives (hereafter TNA) London, War Office (hereafter WO) 33/416, "Military Report on German South-West Africa, 1906"; TNA, WO 33/416, "Military Report on German South-West Africa, 1906", Addendum I, May 1908; TNA, WO 33/416, "Military Report on German South-West Africa, 1906", Addendum II, October 1910; TNA, WO 33/666, "Military Report on German South-West Africa, 1913", Part I. See also E. Ottweiler, "Die Niederschlagsverhältnisse von DeutschSüdwestafrika", MA dissertation, Münster University, 1906; T. Rhebock, DeutschSüdwest-Afrika (Dietrich Reimer, Berlin, 1898); and T. Rhebock, Deutschlands Pflichten in Deutsch-Südwestafrika (Dietrich Reimer, Berlin, 1904). 
South African military operations would have to face in the GSWA theatre. However, it is also true to say that there was a definite annual variation of available water sources in the German colony - and the lack of water was destined to prove extremely problematic with regard to the planning of the South African campaign. ${ }^{18}$

The German colony had no perennial rivers apart from those on its northern and southern boundaries. The remaining watercourses were non-perennial and became gushing torrents for short periods after the arrival of the annual rains. These watercourses - the principal being the Kuiseb, Swakop, Ugab, Konkip, Omatako and Great Fish Rivers - either drained into the Atlantic Ocean, the Orange River or the Kalahari Desert. The interior of the country remained mostly arid after the passing of the seasonal rains. ${ }^{19}$

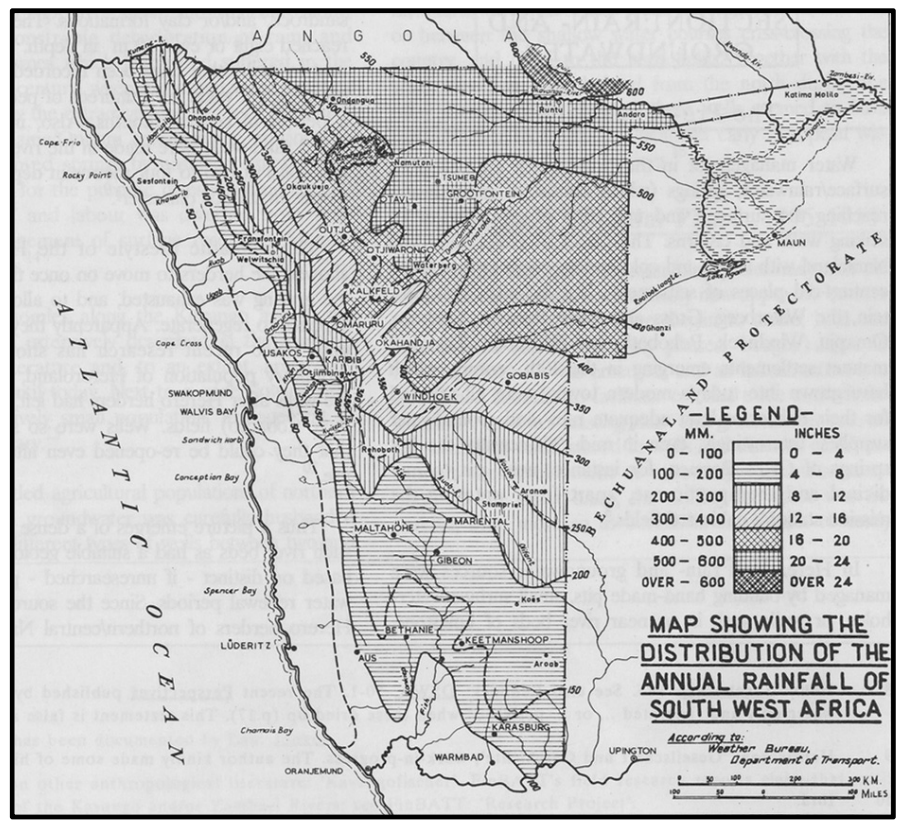

Figure 1: Rainfall Distribution Map of German South West Africa ${ }^{20}$

18. Van der Waag, "Water and Ecology of Warfare in Southern Africa”, p 120; and Van der Waag, A Military History of Modern South Africa, p 96.

19. British Foreign Office, German African Possessions, Volume 18, No. 112: South West Africa (H.M. Stationary Office, London, 1920), p 4; and Bruwer, South-West Africa, pp 8-9.

20. C. Stern and B. Lau, Namibian Water Resources and their Management: A Preliminary History (National Archives of Namibia, Windhoek, 1990), p 3. 
There were two discernible rainy seasons in GSWA. The regular rains typically began to fall during January and continued into April, while earlier rains fell as early as September in some years. The rains also tended to be erratic and differed from year to year. As such, periodic droughts, occasional floods and severe surface water run-off were all common in the territory. These conditions had a significant impact on the planning for military operations. The rainfall was much higher in the northeast of the colony, with a steady decrease in the average precipitation as one moved southwards and westwards to the coastal belt (see Figure 1). ${ }^{21}$

The average annual rainfall for the northern, central and southern parts of GSWA, taken over a ten year period from the 1903/1904 season to the 1912/1913 season, was recorded as $483 \mathrm{~mm}, 353 \mathrm{~mm}$ and $162 \mathrm{~mm}$ respectively. ${ }^{22}$ These figures are, however, too generalised to be useful and become problematic when planning military operations. The coastal belt, for instance, received far less than these projected numbers. The annual rainfall statistics for the principal localities in GSWA from 1912/1913 to 1914/1915 confirms this (see Table 1). Furthermore, the height of the rainy season coincided with a period of extremely high temperatures which in turn led to large-scale evaporation. ${ }^{23}$ In sum, surface water sources were scarce and provided only limited amounts of water. The climate of the colony was healthy, although the limited rainfall and access to water prevented any large-scale concentration of military forces. ${ }^{24}$

21. Lehmann, "Between Waterberg and Sandveld", p 538; Bruwer, South-West Africa, p 9; and Winters et al, Battling the Elements, p 250.

22. South African National Weather Service, Reference Library, Pretoria, (hereafter SANWS), File 9900, South West Africa Annual Reports, 1911-1930, “Jahresbericht über das meteorologische Beobachtungswesen im südwestafrikanischen Schutzgebiet für die Zeit vom 1 Juli 1912 bis 30 Juni 1913"; SANWS, File 9900 South West Africa Annual Reports 1911-1930, "Jahresbericht über das meteorologische Beobachtungswesen im südwestafrikanischen Schutzgebiet für die Zeit vom 1 Juli 1911 bis 30 Juni 1912". See also SANWS, File 9900, South West Africa Annual Reports, 1911-1930, "Jahresbericht über das meteorologische Beobachtungswesen im südwestafrikanischen Schutzgebiet für die Zeit vom 1 Juli 1910 bis 30 Juni 1911". A number of the figures in these sources have been re-worked by the author to calculate these statistics.

23. Bruwer, South-West Africa, pp 9.

24. General Staff, The Union of South Africa and the Great War, pp 10-12; TNA, WO 33/416, "Military Report on German South-West Africa, 1906", Addendum II October 1910; and TNA, WO 33/666, "Military Report on German South-West Africa, 1913", Part I. 
Kleynhans - The impact of water on the South African Campaign in German South West Africa

\begin{tabular}{|c|c|c|c|c|}
\hline Locality & $\mathbf{1 9 1 2 / 1 9 1 3}$ & $\begin{array}{c}\mathbf{1 9 1 3} / \mathbf{1 9 1 4} \\
\text { Coastal Belt }\end{array}$ & $\mathbf{1 9 1 4} / \mathbf{1 9 1 5}$ & Average \\
\hline Lüderitz & $10.4 \mathrm{~mm}$ & $13.7 \mathrm{~mm}$ & $16.0 \mathrm{~mm}$ & $\mathbf{1 3 . 4} \mathbf{~ m m}$ \\
\hline Swakopmund & $8.2 \mathrm{~mm}$ & $6.6 \mathrm{~mm}$ & $22.1 \mathrm{~mm}$ & $\mathbf{1 2 . 3} \mathbf{~ m m}$ \\
\hline Warmbad & $94.3 \mathrm{~mm}$ & $82.3 \mathrm{~mm}$ & $63.5 \mathrm{~mm}$ & $\mathbf{8 0 . 0} \mathbf{~ m m}$ \\
\hline Keetmanshoop & $54.1 \mathrm{~mm}$ & $136.1 \mathrm{~mm}$ & $87.6 \mathrm{~mm}$ & $\mathbf{9 2 . 6} \mathbf{~ m m}$ \\
\hline Gibeon & $66.7 \mathrm{~mm}$ & $73.7 \mathrm{~mm}$ & $87.1 \mathrm{~mm}$ & $\mathbf{7 5 . 8} \mathbf{~ m m}$ \\
\hline Rehoboth & $225.3 \mathrm{~mm}$ & $104.1 \mathrm{~mm}$ & $229.9 \mathrm{~mm}$ & $\mathbf{1 8 6 . 4} \mathbf{~ m m}$ \\
\hline Gobabis & $447.8 \mathrm{~mm}$ & $215.4 \mathrm{~mm}$ & $322.3 \mathrm{~mm}$ & $\mathbf{3 2 8 . 5} \mathbf{~ m m}$ \\
\hline Windhoek & $244.8 \mathrm{~mm}$ & $235.2 \mathrm{~mm}$ & $336.6 \mathrm{~mm}$ & $\mathbf{2 7 2 . 2} \mathbf{~ m m}$ \\
\hline Grootfontein & $751.8 \mathrm{~mm}$ & $469.9 \mathrm{~mm}$ & $383.5 \mathrm{~mm}$ & $\mathbf{5 3 5 . 1} \mathbf{~ m m}$ \\
\hline Tsumeb & $738.6 \mathrm{~mm}$ & $461.7 \mathrm{~mm}$ & $446.5 \mathrm{~mm}$ & $\mathbf{5 4 8 . 9} \mathbf{~ m m}$ \\
\hline Outjo & $540.8 \mathrm{~mm}$ & $388.6 \mathrm{~mm}$ & $273.3 \mathrm{~mm}$ & $\mathbf{4 0 0 . 9} \mathbf{~ m m}$ \\
\hline
\end{tabular}

Table 1: Annual Rainfall Statistics for German South West Africa, 1912-1915 25

The discussion above clearly demonstrates the acute importance of rain and water on the military operating environment of GSWA. It was imperative to strategise on the management of the German colony's available water sources before the outbreak of war. Historically the territory's water sources are divided into seven categories: rain and groundwater; dams; pumped water from boreholes; artesian water; water from running rivers; fresh water gained by desalination; and water won through a combination of several of these sources. ${ }^{26}$ In the German colonial era (1895-1915), the surface and groundwater resources remained precarious. An active rainwater management programme was implemented to quench the "thirst" of the growing settler economy. Although drilling boreholes remained the primary mode of water provision in the colony, other measures were introduced to help manage the available groundwater. These included sinking large wells in river beds, building experimental sand storage dams, the construction of ground weirs and the harnessing of springs and fountains. ${ }^{27}$

Between 1895 and 1914 the German government constructed at least 500 farm dams in GSWA. Some of these were of considerable capacity. Before the outbreak of the war, seven major dam schemes had been planned, which included the Fish River Terracing Scheme as well as the De Naauwte dam project - the latter with a planned capacity of 70 million $\mathrm{m}^{3} \cdot{ }^{28}$ However, boreholes remained the primary water supply for farmers, and for residents in towns and villages. The drilling of

25. Union Office of Census and Statistics, Official Yearbook of the Union and of Basutoland, Bechuanaland Protectorate and Swaziland, No. 5, 1922 (Government Printer, Pretoria, 1923), p 944.

26. Stern and Lau, Namibian Water Resources and their Management, pp 2-3.

27. Stern and Lau, Namibian Water Resources and their Management, pp 5-15.

28. Stern and Lau, Namibian Water Resources and their Management, pp 26-55. 
boreholes became centralised in 1906, and two drilling squads were responsible for drilling boreholes in the north and south of the colony. These units operated under the supervision of a geologist and could drill up to 100 boreholes per year. Artesian springs also supplemented the other sources of groundwater. ${ }^{29}$

Furthermore, the South African defence planners were aware that the towns of Swakopmund and Lüderitzbucht were both entirely dependent on water supplies produced by the pumping station at Swakopmund and the water condensers at Lüderitz. But together, these schemes provided barely enough drinking water for the inhabitants of the two towns and the South African staff officers recognised that they would struggle to support a large concentration of military forces with adequate water supplies. An advance across the waterless coastal belt would mean that the UDF would have to transport water to the soldiers at the frontline either by mounted transport or making use of the railway line. Doing so would supplement the water gained from the known waterholes and springs in the German colony. Before the war, the German colony often relied on water being shipped from Cape Town by tank steamers to Lüderitzbucht. The water was then transported inland as the need required. ${ }^{30}$ The South African staff officers appreciated the fact that the control of water sources would be one of the key factors in the success of the South African campaign, and their plans for the invasion thus incorporated the securing of access to water sources along the different routes of advance.

\section{The influence of water on the South African military operations}

The plan for the invasion of GSWA was finalised by the staff officers at Defence Headquarters on 21 August 1914. It allowed for three separate columns to converge on the colony. Colonel P.S. Beves and his 'C' Force, which comprised 1200 rifles and six guns, was to land at Lüderitzbucht and capture the wireless infrastructure, while the Royal Navy would destroy other essential infrastructure at Swakopmund by naval bombardment. Further south, Brig. Gen. H.T. Lukin and his 'A' Force, comprising 1 800 rifles and eight guns, would land at Port Nolloth and advance on the German border. To the east, Lt Col S.G. Maritz and his 'B' Force, comprising 1000 rifles, would invade GSWA with Upington as its base of operations. ${ }^{31}$

29. TNA, WO 33/666, "Military Report on German South-West Africa, 1913", Part I; and Stern and Lau, Namibian Water Resources and their Management, pp 63-65.

30. TNA, WO 33/416, "Military Report on German South-West Africa, 1906"; TNA, WO 33/416, "Military Report on German South-West Africa, 1906", Addendum I, May 1908; TNA, WO 33/416, "Military Report on German South-West Africa, 1906", Addendum II, October 1910; TNA, WO 33/666, "Military Report on German SouthWest Africa, 1913", Part I. See also National Archives and Records Service of South Africa, Pretoria (hereafter NARSA), Smuts Papers (A1), Box 112, Major-General C.W. Thompson, "Report on a Visit to German South West Africa in Attendance of His Excellency the Governor-General of the Union of South Africa", 20-27 March 1915.

31. Strachan, The First World War in Africa, p 69; and Kleynhans, "South African Invasion of German South West Africa (Union of South Africa)". 
However, the plan for the invasion of GSWA suffered from several flaws which were destined to have a distinct impact on the opening salvos of the military campaign. First, the three fighting columns were to be deployed across a vast operational area stretching over an arch of 900 kilometres from Lüderitzbucht to Upington. This meant that lateral communication between the forces would be almost impossible due to large geographic distances; harsh terrain; poor communication infrastructure; and the divided command. Another error of planning was the decision to control operations centrally from Defence Headquarters in Pretoria, which made careful timing and coordination of the South African offensive operations virtually impossible. ${ }^{32}$

On 16 September the South African parliament approved the invasion of GSWA. On the operational front events now moved swiftly. Colonel Beves successfully occupied Lüderitzbucht with his force on 18 September and accounted for his objectives immediately, while the Royal Navy bombarded Swakopmund. However, Beves was unable to move inland because the retreating German forces had destroyed the railway line to Aus. ${ }^{33}$ On 12 September, General Lukin had ordered his troops to occupy the high ground and border posts at Raman's Drift, Houms Drift, and Gudous before the invasion of GSWA commenced. He had planned to invade GSWA from across the Orange River and then advance on Seeheim via Raman's Drift, Warmbad and Kalkfontein. The biggest obstacle to Lukin's planned operations remained access to sufficient water for his force along his proposed route of advance. He therefore ordered a small force of South African troops to occupy and hold the waterholes at Sandfontein on 19 September while he halted at Raman's Drift to await the arrival of the necessary supplies and reinforcements for the invasion. ${ }^{34}$

Defence Headquarters, however, pressured him to occupy Sandfontein in force and hasten his advance on Warmbad. Van der Waag argues that two pieces of intelligence had influenced the South African decision to cross the frontier hastily. The first was some scant information that the German troops were destroying waterholes and wells on their side of the border, while the other piece of information pointed to the confirmed concentration of the Schutztruppen on the eastern border of GSWA. ${ }^{35}$ On 26 September, a South African force under Lt. Col R. Grant suffered a crushing defeat at Sandfontein at the hands of Col J. von Heydebreck and his Schutztruppen. Colonel Heydebreck made good use of the terrain, his interior lines of communications and his superior forces at Sandfontein to concentrate and defeat the South Africans. Moreover, Maritz caused great concern when he failed to send Lukin reinforcements and openly supported the Germans by sharing military information

32. Van der Waag, "The Battle of Sandfontein", pp 148-149.

33. Garcia, "Manoeuvre Warfare", pp 49-51; and Van der Waag, A Military History of Modern South Africa, pp 97-98.

34. R.C. Warwick, "The Battle of Sandfontein: The Role and Legacy of Major General Sir Henry Timson Lukin", Scientia Militaria, 34, 2 (2006), pp 73-75.

35. Van der Waag, "The Battle of Sandfontein", pp 149-150. 
with them on the South African dispositions around Sandfontein. ${ }^{36}$ On 9 October Maritz went into open rebellion with the majority of his force at Upington. This move followed the resignation of several other officers and men from the UDF during September in protest of the South African decision to invade the neighbouring GSWA. Soon afterwards, Defence Headquarters was forced to call an immediate halt to all offensive operations in GSWA. Pretoria realised that it first needed to reorganise the UDF and deal with the all-out Afrikaner Rebellion that was festering inside its borders before it could re-focus on the complete invasion of GSWA. ${ }^{37}$

By January 1915 the Afrikaner Rebellion had been successfully crushed in the Union and the focus once more shifted to the conquest of GSWA. The minister of defence, General J.C. (Jan) Smuts decided to draw up a new plan for the invasion of the German colony. He decided to use Swakopmund and Walvis Bay as staging areas for a direct advance on Windhoek. General L. (Louis) Botha, the South African prime minister, then assumed the overall command of the South African invasion which ensured unity of command at both the political and military spheres of the campaign. Jan Smuts believed that separate attacks along four different axes would deny the German forces the use of their interior lines of communication and the concentration of their troops, and ensure the UDF's operational success. Generals Botha and Smuts also aimed to destroy the Schutztruppen in the field, and in doing so prevent a guerrilla campaign from ensuing. ${ }^{38}$

Four different forces converged on GSWA in early January 1915. In the north, under the personal command of Botha, the Northern Force operated from Walvis Bay and threatened the German military and political seat at Windhoek. The Northern Force was the principal South African force in the field. Under the command of Lt Col C.A.L. Berrangé, the Eastern Force operated from Kuruman and was tasked with threatening the eastern border of GSWA through an advance across the Kalahari Desert. The Central Force was commanded by Brig. Gen. Sir D. McKenzie and was tasked to move forward from Lüderitzbucht via Aus towards the strategic railroad juncture at Seeheim, and then threaten Keetmanshoop. The Southern Force, under the command of Col J.L. van Deventer, would threaten the south of GSWA from their bases at Upington and Port Nolloth. ${ }^{39}$

36. Warwick, "The Battle of Sandfontein", pp 73-77. See also R.C. Warwick, "Reconsideration of the Battle of Sandfontein: The First Phase of the German South West Africa Campaign, August to September 1914", MA dissertation, University of Cape Town, 2003.

37. Garcia, "Manoeuvre Warfare”, pp 56-63.

38. Van der Waag, "The Battle of Sandfontein", p 155.

39. Strachan, The First World War in Africa, p 82; Trew, Botha Treks, p 60; and Garcia, "Manoeuvre Warfare", p 64. 
Kleynhans - The impact of water on the South African Campaign in German South West Africa

\begin{tabular}{|c|c|c|c|c|c|}
\hline & Artillery & Mounted & Infantry & Administrative & Total \\
\hline $\begin{array}{l}\text { Northern } \\
\text { Force }\end{array}$ & 741 & 12773 & 5864 & 1491 & $\begin{array}{c}20869 \\
\text { men }\end{array}$ \\
\hline $\begin{array}{c}\text { Central } \\
\text { Force }\end{array}$ & 575 & 3858 & 5583 & 855 & $\begin{array}{c}10871 \\
\text { men }\end{array}$ \\
\hline $\begin{array}{c}\text { Southern } \\
\text { Force }\end{array}$ & 117 & 8438 & \#\#\# & 631 & $\begin{array}{l}9186 \\
\text { men }\end{array}$ \\
\hline $\begin{array}{c}\text { Eastern } \\
\text { Force }\end{array}$ & 40 & 2016 & \#\#\# & 420 & $\begin{array}{l}2476 \\
\text { men }\end{array}$ \\
\hline Total & $\begin{array}{l}1473 \\
\text { men }\end{array}$ & $\begin{array}{c}27085 \\
\text { men }\end{array}$ & $\begin{array}{c}11447 \\
\text { men }\end{array}$ & $\begin{array}{l}3397 \\
\text { men }\end{array}$ & $\begin{array}{c}43402 \\
\text { men }\end{array}$ \\
\hline
\end{tabular}

Table 2: Summary of Troops in the Field on 15 March $1915^{40}$

The South African military operations conducted during the second invasion of GSWA, began in all earnest during February 1915. By mid-March, and with the renewed UDF offensive operations underway, the number of Union troops on active service in the field reached its peak at 43402 men. Of these 27085 were mounted infantry (see Table 2). The UDF launched a number of attacks along the four different axes of advance and captured some key German towns between March and June 1915. These were: Aus (31 March); Kalkfontein (5 April); Kabus (20 April); Gibeon (27 April); Karibib (5 May); Windhoek (12 May); and Namutoni (6 July). The principal battles of the campaign were fought at Riet-Pforte and Jakkalswater (20 March); Kabus (20 April); Trekkoppies (26 April); Gibeon (26-27 April); and Otavifontein (1 July). The German forces surrendered at Otavifontein on 9 July $1915 .{ }^{41}$

The nexus between the access to and supply of water, and the military operations outlined above, were intrinsic, to say the least. The UDF operations were reliant on water and to some extent, water dictated the pace and scope of all military advances within GSWA. The daily water ration per soldier during the campaign was 6.8 litres, while horses received 31.8 litres per day. ${ }^{42}$ The UDF required approximately 295133 litres of water per day to meet its logistical requirement to its troops in the field alone (see Table 3). In addition, the 27085 mounts required a further 861302 litres of water per day. The UDF thus had the immense responsibility of providing a total of 1156435 litres of water per day to meet the ration requirements of its forces in the field. This perhaps explains why of the 133 days the UDF spent on operations in GSWA, only 24 days comprised actual operational movements. The remaining 109 days were devoted to accumulating sufficient logistical supplies, including adequate water supplies, to continue the South African

40. General Staff, The Union of South Africa and the Great War, $\mathrm{p} 60$.

41. General Staff, The Union of South Africa and the Great War, pp 29-54, 60; and Van der Waag, "The Battle of Sandfontein", p 158.

42. NARSA, Smuts Papers (A1), Box 112, Thompson, "Report on a Visit to German South West Africa in Attendance of His Excellency the Governor-General of the Union of South Africa", 20-27 March 1915. 
Kleynhans - The impact of water on the South African Campaign in German South West Africa

military advance into the hinterland of the colony. This was because the South African lines of communication were stretched to a maximum owing to the four separate advances into South-West Africa. ${ }^{43}$

\begin{tabular}{|c|c|c|c|c|c|}
\hline & $\begin{array}{l}\text { Northern } \\
\text { Force }\end{array}$ & $\begin{array}{l}\text { Central } \\
\text { Force }\end{array}$ & $\begin{array}{l}\text { Southern } \\
\text { Force }\end{array}$ & $\begin{array}{c}\text { Eastern } \\
\text { Force }\end{array}$ & Total \\
\hline $\begin{array}{c}\text { Total } \\
\text { Troops }\end{array}$ & 20869 & 10871 & 20869 & 9186 & $\begin{array}{c}43402 \\
\text { men }\end{array}$ \\
\hline $\begin{array}{c}\text { Water Rations } \\
\text { p/day }\end{array}$ & $\begin{array}{c}141909 \\
\text { litres }\end{array}$ & $\begin{array}{l}73923 \\
\text { litres }\end{array}$ & $\begin{array}{l}62465 \\
\text { litres }\end{array}$ & $\begin{array}{l}16836 \\
\text { litres }\end{array}$ & $\begin{array}{c}295133 \\
\text { litres } \\
\text { p/day }\end{array}$ \\
\hline $\begin{array}{l}\text { Estimated } \\
\text { Mounts }\end{array}$ & 12773 & 3858 & 8438 & 2016 & $\begin{array}{l}27085 \\
\text { horses }\end{array}$ \\
\hline $\begin{array}{c}\text { Water Rations } \\
\text { p/day }\end{array}$ & $\begin{array}{c}406181 \\
\text { litres }\end{array}$ & $\begin{array}{c}122684 \\
\text { litres }\end{array}$ & $\begin{array}{c}268328 \\
\text { litres }\end{array}$ & $\begin{array}{l}64109 \\
\text { litres }\end{array}$ & $\begin{array}{c}861302 \\
\text { litres } \\
\text { p/day }\end{array}$ \\
\hline $\begin{array}{c}\text { Total Water } \\
\text { Needed } \\
\text { p/day }\end{array}$ & $\begin{array}{c}548090 \\
\text { litres } \\
\text { p/day }\end{array}$ & $\begin{array}{c}196607 \\
\text { litres } \\
\text { p/day }\end{array}$ & $\begin{array}{c}330793 \\
\text { litres } \\
\text { p/day }\end{array}$ & $\begin{array}{c}80945 \\
\text { litres } \\
\text { p/day }\end{array}$ & $\begin{array}{l}1156435 \\
\text { litres } \\
\text { p/day }\end{array}$ \\
\hline
\end{tabular}

Table 3: Water Requirements of the Union Troops in the Field, 15 March $1915^{44}$

To meet the ever growing water demand during the GSWA campaign, the UDF had to rely on a number of methods to supplement its water needs. The key advances of the Northern and Central Forces, from Swakopmund and Lüderitzbucht respectively, were reliant on the water provided by the water pumping station at Swakopmund and the water condenser at Lüderitzbucht but together they were only capable of a limited supply of water per day.45 In fact, Maj. Gen. C.W. Thompson - the British GOC of the South African Military Command - concluded that water was the chief anxiety of the campaign. When the German forces retreated from Swakopmund, they destroyed the water tanks, which placed a further burden on the water supplies.

What measures were taken to alleviate the shortage of water? After extensive digging the brackish water found in the bed of the Swakop River augmented the water supply at Swakopmund. Then too, the fresh water shipped from Cape Town was mixed with the brackish water to make it more potable. During February and March of 1915, good rains fell in the interior of the country, which helped to ease the provision of water. During March 1915 the pumping station at Lüderitzbucht produced approximately 218000 litres of water per day, with an average storage capacity of 331000 litres. According to the Thompson Report of March 1915, drafted

43. Garcia, "Manoeuvre Warfare", p 117.

44. This table was compiled from General Staff, The Union of South Africa and the Great War, p 60; and NARSA, Smuts Papers (A1), Box 112, Thompson, "Report on a Visit to German South West Africa in Attendance of His Excellency the Governor-General of the Union of South Africa", 20-27 March 1915.

45. TNA, WO, 33/416, "Military Report on German South-West Africa, 1906". 
after General Thompson's visit to GSWA, the daily consumption of water at Lüderitzbucht was calculated at 355000 litres. This figure is, however, slightly larger than the projected number in Table $3 .{ }^{46}$ In some instances, the local demand for water still outstripped the local supply. At both Lüderitzbucht and Swakopmund, the local supply of water was increased by water shipped in from Cape Town. The SS Monarch transported approximately 3.4 million litres of fresh water from Table Mountain to GSWA on each of her trips during the campaign. Furthermore, when the Monarch was alongside at Lüderitzbucht, she condensed more than 59000 litres of sea water daily to add to the local supply of drinking water. ${ }^{47}$

Once the South African advance had crossed the waterless stretch of the coastal belt, some boreholes were sunk to supplement the supply of local and shipborne water from Cape Town. By the end of April, under the guidance of George Farrar, the assistant quartermaster-general, the entire water supply was rearranged. The South African Engineer Corps (SAEC) sunk a large number of boreholes along the various routes of advance to provide the UDF troops with more water. ${ }^{48}$ Sir Thomas Cullinan served under the command of Berrangé in the Eastern Force and was responsible for the drilling of boreholes on their route of advance into GSWA. ${ }^{49}$ The water at each of these boreholes was analysed to determine whether it was safe for drinking or mechanical purposes. Officers of the South African Medical Corps (SAMC) carried out these tests, and the results were then reported to the director of military services in Pretoria as well as the officer commanding Base and Lines of Communication. ${ }^{50}$ At Garub, for instance, the three boreholes that were sunk by Farrar and his teams were capable of supplying 227000 litres of water per day by the end of March. Water from these boreholes was stored in cisterns, and a concrete dugout pit, that could hold approximately 910000 litres of water. 51

46. NARSA, Smuts Papers (A1), Box 112, Thompson, "Report on a Visit to German South West Africa in Attendance of His Excellency the Governor-General of the Union of South Africa", 20-27 March 1915; and Van der Waag, "The Battle of Sandfontein", p 157.

47. NARSA, Smuts Papers (A1), Box 112, "Report on the Visit of the Governor-General of the Union of South Africa to German South-West Africa", 20-27 March 1915; TNA, WO, 33/416, "Military Report on German South-West Africa, 1906"; and Rayner and O'Shaughnessy, How Botha and Smuts Conquered German South West Africa, p 26.

48. Van der Waag, "The Battle of Sandfontein", p 157.

49. University of Witwatersrand, William Cullen Library, Wits Historical Papers (hereafter WITS), Sir Thomas Cullinan Collection (ZA HPRA A731), File A731-A-Ab-2, "Notebooks Concerned with Water for Horses and the Construction of a Telegraph", 17 March to 4 April 1915.

50. South African Department of Defence Archives (hereafter DOD Archives), Secretary for Defence (hereafter DC), Group 2, Box 719, File G1229/9199, Water: Analysis Thereof, "Reports on Analysis of Water Samples from the A.D.M.S Southern Army to the General Staff”, 15 June 1915.

51. NARSA, Smuts Papers (A1), Box 112, Thompson, "Report on a Visit to German South West Africa in Attendance of His Excellency the Governor-General of the Union of South Africa", 20-27 March 1915. 
The UDF used the railways, motorised and animal transport to move the water forward along the various routes of advance. In general, water was transported some distance to the front by rail. From here, two-wheeled water carts carried the water to the van of the fighting columns. It is of interest to note that the number of water carts attached to Botha's Northern Force alone, increased by approximately threefold from 1 March to 12 April 1915, going up from 51 to 165 water carts. ${ }^{52}$ However, the corrosive nature of the water found in Walvis Bay, Swakopmund, Nonidas and Usakos, proved extremely detrimental to the railway locomotives that transported water to the frontline. Prolonged use of this water caused a rusting scale in the boilers of the engines, and eventually corroded the tubing as well. By adding a boiler liquid to the untreated water, it was estimated that the railway locomotives could function for two months before it was necessary to re-tube the entire engine. These locomotives furthermore used a large amount of "clean" water daily to function optimally. This added a further, albeit necessary, burden to the already stretched South African lines of communication. ${ }^{53}$ The South African advance across the Kalahari succeeded because up to forty motor vehicles were used to establish water dumps along the desired route of advance in a series of tactical leaps and bounds. The mounted infantry of the Eastern Force successfully used these water dumps to cross waterless stretches of the Kalahari Desert. ${ }^{54}$ Once the South African forces reached the fertile northern region of the colony, their water troubles eased because good rains had fallen there in 1915 and this ensured a plentiful water supply for men, machines and animals. ${ }^{55}$

52. Garcia, "Manoeuvre Warfare", pp 96-97; and Van der Waag, "The Battle of Sandfontein", p 157.

53. DOD Archives, DC, Group 2, Box 719, File G1229/9199, Water: Analysis Thereof, "Report from Assistant Director of Military Railways to Director of Military Railways re the Effect of Water from Walvis Bay, Swakopmund, Nonidas and Usakos on Locomotive Boilers", 26 May 1915; DOD Archives, DC, Group 2, Box 719, File G1229/9199, Water: Analysis Thereof, "Letter from Mr D. Ryde-Cassel to the Director of Railways on the Analysis of Water from Walvis Bay, Swakopmund, Nonidas and Usakos and its Effect on Locomotive Boilers", 25 May 1915; and DOD Archives, DC, Group 2, Box 719, File G1229/9199 Water: Analysis Thereof, "Notice to Engine Drivers and All Concerned on the Treatment of Water for Use as Boiler Fluid", 26 May 1915.

54. DOD Archives, WW1 German South-West Africa (hereafter WW1 GSWA), Box 20, "Report by Colonel C.L.A Berrangé on the Formation and Operations of the Eastern Force in German South-West Africa up to 15 May 1915"; and Collyer, The Campaign in German South West Africa, 1914-1915, p 161.

55. Union Office of Census and Statistics, Official Yearbook of the Union and of Basutoland, Bechuanaland Protectorate and Swaziland, p 944; and NARSA, Smuts Papers (A1), Box 112, Thompson, "Report on a Visit to German South West Africa in Attendance of His Excellency the Governor-General of the Union of South Africa", 20-27 March 1915; and Van der Waag, "The Battle of Sandfontein", p 157. 


\section{The German poisoning of water sources}

When the South African forces arrived in GSWA during 1914, it soon became apparent that the German forces were deliberately poisoning the fresh water supplies in the colony as part of their military strategy. ${ }^{56}$ Ian van der Waag states categorically that local forces who enjoy the "... strategic advantage... [can] control the tempo of warfare by maximising their knowledge of terrain and climate, refusing battle and adopting guerrilla strategies". ${ }^{57}$ This was particularly true of the German military operations in GSWA during the war. From November 1914, the Schutztruppen, commanded by Maj. E.V.C.A (Victor) Franke, adopted a Fabian strategy for the remainder of the campaign into 1915. The German plan was to retain sufficient territory to uphold Germany's claim to the colony when the peace negotiations were held. As such, the German forces avoided pitched battles and frontal assaults and chose instead to wear down the South African foe by resorting to a calculated war of attrition. Franke realised that this approach would disrupt the South African supplies and place severe strain on the UDF's already extended lines of communication. The poisoning of water throughout the campaign formed a crucial part of this Fabian strategy. 58

The UDF troops that landed at Walvis Bay in the latter half of 1914, and subsequently occupied Swakopmund, immediately established that the water at Sandfontein, near Walvis Bay, and Swakopmund, had been poisoned and was not fit for human or animal consumption. At Sandfontein it was reported that dead animals had been thrown into the water, while at Swakopmund, arsenic cattle dip was used to poison the drinking water in no less than six wells. ${ }^{59}$ The South African staff officers realised they had to act immediately. A directive was passed that German prisoners would be asked to drink freely from all water supplies so it could be ascertained whether or not the water had been poisoned. This was a harsh but necessary step; it was the only way to determine whether the water was safe to drink. ${ }^{60}$

56. DOD Archives, DC, Group 2, Box 668, File 848/9199, Poisoned Water in GSWA, "Report on work of Sanitation Section and Sanitary Conditions during Campaign in German South West Africa", September 1914 to August 1915; Garcia, "Manoeuvre Warfare", pp 48, 67, 74; and Van der Waag, "The Battle of Sandfontein", pp 148, 157.

57. Van der Waag, "Water and Ecology of Warfare in Southern Africa”, p 199.

58. D.R. Clonts, "A Dilemma of War: Decisive Force vs Fabian Strategy", MA dissertation, University of Denver,1999, pp 16-18; and Strachan, The First World War in Africa, pp 88-89.

59. DOD Archives, DC, Group 2, Box 668, File 848/9199, Poisoned Water in GSWA, "Sworn Statement by Sapper 0.C. King re Water Testing at Swakopmund", 13 July 1915; and DOD Archives, DC, Group 2, Box 668, File 848/9199, Poisoned Water in GSWA, "Report on Work of Sanitation Section and Sanitary Conditions during Campaign in German South West Africa”, September 1914 to August 1915.

60. DOD Archives, DC, Group 2, Box 668, File 848/9199, Poisoned Water in GSWA., "Secret Correspondence between the Director of Medical Services and the Secretary for Defence re Water Analysis", 1 March 1915. 
The discovery that the German forces were systematically poisoning the water supplies prompted the UDF to organise that water analysts would accompany each independent fighting column. This specialist section of troops was required to test and examine the water sources before they were deemed safe for consumption and had to report directly to the SAMC. Upon joining the section, each analyst had to undergo specialist courses in water testing, water pollution and water purification. They were then deployed in the field where they were required to test all water for poisons and to facilitate the purification and disinfection of water for drinking purposes. Initial tests focused upon the odour, colour and general appearance of the water before a full sample was analysed. ${ }^{61}$ The lengthy procedures used to test water for bacteria and poisons forced the analysts to treat all water sources as bacteriologically impure. When the analysts arrived at a well, they conducted a chemical analysis of the water, and while awaiting the results they added chloride of lime to the water source to give a resulting solution of 1 in 1000000 free chlorine. Once the analysis of the water was completed, the officer commanding the column and the senior medical officer were informed whether the water was safe for human and animal consumption. In most cases the water was found to be free from bacteriological organisms and the chlorine that had been added acted as an efficient disinfectant. However, chlorination did not render the waters entirely safe and the UDF troops were instructed to boil and sterilise their drinking water as an extra precaution to minimise the risk of bacterial poisons. If the analysts discovered that the water had been poisoned, a board was fixed to the location with the words "Poisoned" and "Vergift" written on them. ${ }^{62}$

The poisoning of the water sources in GSWA was a deliberate attempt by the German forces under Franke to disrupt the speed of the South African operational advances. On numerous occasions, Louis Botha informed the German governor of South West Africa, Dr T. (Theodor) Seitz, that Franke's Schutztruppen were contravening the Hague Convention, which governed the conduct of war. ${ }^{63}$ The poisoning of the wells was in direct contravention of the Hague Convention. Article 23 (a) of explicitly forbids the employment of "poison or poisoned weapons" as a means

61. DOD Archives, DC, Group 2, Box 668, File 848/9199, Poisoned Water in GSWA, "Secret Correspondence between the Director of Medical Services and the Secretary for Defence re Poisoning of Water in Swakopmund", 26 February 1915; and DOD Archives, DC, Group 2, Box 668, File 848/9199, Poisoned Water in GSWA, "Report on Work of Sanitation Section and Sanitary Conditions during Campaign in German South West Africa", September 1914 to August 1915.

62. DOD Archives, DC, Group 2, Box 668, File 848/9199, Poisoned Water in GSWA, "Report on Work of Sanitation Section and Sanitary Conditions during Campaign in German South West Africa", September 1914 to August 1915.

63. DOD Archives, DC, Group 2, Box 668, File 848/9199, Poisoned Water in GSWA, "Correspondence between Botha and Smuts re Correspondence to Seitz and Franke Regarding German Breaches of Hague Convention during the Conduct of the Campaign, 18 April 1915 (Copies A-H). 
of conducting war. ${ }^{64}$ Theodor Seitz, however, casually commented that all watering places could be categorised as "war materiel" which could be used by the South Africans in their conduct of the campaign and that his German forces thus had the right to "destroy" all water sources. ${ }^{65} \mathrm{He}$ further stated:

"Poisoning" I understand to mean secretly adding matter which is injurious to the health of human beings. What, on the other hand, has been done with my permission, and will continue to be done, is merely affecting a change in the natural condition of the water in order to deprive the enemy of the use of this means of existence, which under South African conditions can only be replaced with difficulty ... you must order that your troops in future are only to use water in GSWA after it has been chemically examined. 66

Throughout the campaign, Franke and Seitz maintained that all the water sources that were rendered "useless" - as they nonchalantly referred to their poisoning efforts - was marked with the appropriate signage which indicated as much. According to the South African testimonies and sworn statements, no such warning signs were ever found. ${ }^{67}$ The South African troops did, however, find evidence which suggested that the poisoning of the water sources were a concentrated effort ordered by the German authorities. It appears that the poisoning began shortly after the Battle of Sandfontein in September 1914.68

On four separate occasions, the South African forces in GSWA found items of incriminating correspondence which indicated that the Schutztruppen were indeed deliberately poisoning water sources during the campaign. This evidence read:

- "I request if possible today information as to what quantity and what means are necessary to render five hundred cubic metres of water undrinkable for a lengthy period." 69

64. DOD Archives Reference Library, Blue Books, Appendix D to the "Report of the Committee on Alleged German Outrages", 1915, Convention Concerning the Laws and Customs of War on Land".

65. DOD Archives Reference Library, Blue Books, "German Atrocities, and Breaches of the Rules of War in Africa”, July 1916, German South West Africa: Correspondence between Seitz and Botha, 25 June 1915.

66. DOD Archives, DC, Group 2, Box 668, File 848/9199, Poisoned Water in GSWA, Correspondence between Franke and Botha, 11 March 1915.

67. Delport, "Boks and Bullets, Coffins and Crutches", p 67.

68. DOD Archives, DC, Group 2, Box 668, File 848/9199, Poisoned Water in GSWA, "Provost Marshal Examination of Two Officers of the German Medical Corps Captured in GSWA (Dr Elsberger and Captain Schmidt)", 14 May 1915.

69. DOD Archives, DC, Group 2, Box 668, File 848/9199, Poisoned Water in GSWA, "Telegram between Maj Bauzus at Aus and Dr Sieber [Director of Government Laboratory at Gamams]", 15 February 1915. 
- "Arrived at Nonidas; request new cornered bottles."70

- "At the request of Colonel Franke and Captain Weck I am forwarding you a further quantity of Sterbevirus for your use. I shall be glad to have information as to its efficacy."71

- "The patrol [at] Gabib has been instructed thoroughly to infect with disease the Ida Mine. Approach Swakop and Ida Mine with extreme caution and do not water there any more" ${ }^{72}$

It was established by testing procedures that the water at Sandfontein, Swakopmund, Nonidas, Husab, Ida Mine, Heigeunchals, Riet, Trekkopjes, Bullsbout, Omaongombe, Arandis, Okahandja and Aus were poisoned during the UDF's campaign into GSWA. ${ }^{73}$

In light of the serious accusations levelled against Seitz and Franke in their conduct of the war, the South African authorities were forced to take drastic steps. The UDF ordered a number water samples from poisoned water sources, as well as suspicious bacterial cultures found at the German Bacteriological Laboratory at Gamams near Windhoek, to be sent back to the Union immediately to be tested at the South African Institute of Medical Research. ${ }^{74}$ It was found that some of the water was poisoned with Cresol, a Lysol-like substance, which when ingested causes inflammation of the stomach and a dryness of the mouth and palate, simultaneously exciting great thirst. If horses drank this water it could lead to severe griping.

In other instances, traces of pathogenic bacteria, dysentery organisms, arsenic and a horse sickness virus were found in the water samples. ${ }^{75}$ The officer commanding of the Bacteriological Laboratory at Gamams, Dr H. Sieber, was also

70. DOD Archives, DC, Group 2, Box 668, File 848/9199, Poisoned Water in GSWA, "Message from Lt Berger at Arandis to Dr Sieber", 24 February 1915.

71. DOD Archives, DC, Group 2, Box 668, File 848/9199, Poisoned Water in GSWA, "Letter from Dr Sieber to Capt Scultetis at Arandis", 26 February 1915.

72. DOD Archives, DC, Group 2, Box 668, File 848/9199, Poisoned Water in GSWA, "Correspondence between Secretary for Defence and the Office of the GovernorGeneral re Message to the Outpost at Pforte re Infection of the Ida Mine with Disease", 14 May 1915.

73. DOD Archives, DC, Group 2, Box 668, File 848/9199, Poisoned Water in GSWA, "Report on Work of Sanitation Section and Sanitary Conditions during Campaign in German South West Africa", September 1914 to August 1915; and DOD Archives, DC, Group 2, Box 668, File 848/9199, Poisoned Water in GSWA, "Notes on Bacteriological Work Performed by Captain E. Douglas Pullon, SAMC, in South West Africa".

74. DOD Archives, DC, Group 2, Box 668, File 848/9199, Poisoned Water in GSWA, "Confidential Correspondence between Department of Interior and Director of Medical Service re Testing of Poisoned Water", 16 July 1915.

75. DOD Archives, DC, Group 2, Box 668, File 848/9199, Poisoned Water in GSWA, "Notes on Bacteriological Work Performed by Captain E. Douglas Pullon, SAMC in South West Africa”. 
questioned about the large number of cultures of typhoid, paratyphoid and various other strains of dysentery organisms found in his laboratory. He vehemently denied the allegations that his laboratory was producing bacteriological cultures used to poison the water sources in GSWA during the war. He did, however, state that a certain Dr Schwartz, who was the medical staff officer to the Schutztruppen, worked with the typhus bacillus extract at the beginning of the war to inoculate the German troops against typhoid. ${ }^{76}$ This same Dr Schwartz was in the vicinity of Sandfontein in September 1914 when the first reports appeared on poisoned of water supplies. ${ }^{77}$ There remained no doubt in the mind of the UDF that the bacterial pollution of water supplies was intentional and at times undertaken by the German military during the campaign in GSWA, and that the bacterial cultures were issued and prepared by the Bacteriological Laboratory at Gamams. ${ }^{78}$

In a letter to the director of Medical Services, Maj. G.D. Maynard stated that the South African Institute of Medical Research was never able to demonstrate that the samples they had examined tested positively for typhoid organisms. However, he made it clear that these would be difficult to isolate because typhoid organisms were very short-lived. He also mentioned that Captain D.E. Pullon had indeed isolated a dysentery bacillus during preliminary testing. Furthermore, Maynard discredited the defensive explanation offered by Dr Sieber about the presence of typhoid strains at Gamams, because numerous dysentery organisms had in fact been found in the laboratory. He suggested that Dr Sieber should close the matter once and for all by making public the instructions sent to him by the German military authorities, and by producing his laboratory records which no doubt indicated when these instructions were carried out, and for what specific purpose Gamams had stocked numerous such strains of dysentery organisms. ${ }^{79}$ Despite the incriminating evidence mentioned above, in the latter half of 1915 the South African authorities eventually dropped their investigations into the poisoning of water in South West Africa for the want of further evidence and testimony. ${ }^{80}$ Major Maynard, however, concluded that:

76. DOD Archives, DC, Group 2, Box 668, File 848/9199, Poisoned Water in GSWA, "Correspondence between Dr Sieber and General Beves re Poisoning of Water with Typhus", 30 August 1915.

77. DOD Archives, DC, Group 2, Box 668, File 848/9199, Poisoned Water in GSWA, "Provost Marshal Examination of Two Officers of the German Medical Corps captured in GSWA [Dr Elsberger and Captain Schmidt]”, 14 May 1915.

78. DOD Archives, DC, Group 2, Box 668, File 848/9199. Poisoned Water in GSWA, "Correspondence between Acting Director Medical Services and Secretary for Defence re Infection of Water by Enemy during Hostilities in SWA", 28 October 1915.

79. DOD Archives, DC, Group 2, Box 668, File 848/9199, Poisoned Water in GSWA, "Correspondence between Acting Director Medical Services and Secretary for Defence re Infection of Water by Enemy during Hostilities in GSWA", 29 September 1915.

80. DOD Archives, DC, Group 2, Box 668, File 848/9199, Poisoned Water in GSWA, Defence Minute D.26/848/9199, "The Infection of Water Supplies with Disease by the Germans in South West Africa”, undated. 
There is no doubt that bacterial pollution of water-supplies of some sort was undertaken by the enemy; the circumstances at Nonidas and Riet prove this, as does the evidence found on captured officers. There is very little reasonable doubt that the material used and issued to the military authorities was prepared at Gamams. ${ }^{81}$

All the evidence points to the fact that the poisoning of water sources during the campaign in GSWA was a deliberate act by the German forces to control the tempo of warfare. By adopting a Fabian strategy, Franke had hoped to disrupt the speed of the South African operational advances during 1915 by poisoning the water sources. While the German poisoning efforts in this regard did not completely halt the South African operational advances, they forced the UDF to adopt a number of stringent measures during the campaign which to some degree retarded the operational advances of its troops in the field. The most important of these measures was the mandatory testing of all water sources by specially trained water analysts before it was deemed safe for consumption. The poisoning of water sources by the German forces in GSWA, although malicious in nature, thus only had a temporary effect on the South African offensive operations during the campaign.

\section{Conclusion}

The South African campaign in GSWA was indeed governed by the access to, and availability of water. The delicate interplay which exists between geography and warfare highlights the fact that all military operations in GSWA were to some extent influenced by water and the want for it. The German forces used water as a military resource during the campaign and did not hesitate to poison water sources to gain the tactical and operational advantage at certain stages of the war. In fact, the German defence of South West Africa was predicated on the fact that water would be one of the biggest obstacles to the South African advance during the campaign due to the arid nature of the military operating environment. While the German poisoning of water sources only provided a minor stumbling block to the UDF's operational progress, the lack of water had a distinct impact on the military operations during the campaign. The large number of South African troops in South West Africa placed a considerable burden upon the UDF's already stretched exterior lines of communication. Operational advances could only be made after stockpiling sufficient logistical supplies - of which water was principal. This process repeated itself throughout the campaign and goes some way to explaining why the South African forces only had 24 days of actual operational movement. The South African efforts to provision its fighting forces with sufficient water remains an extraordinary feat, especially when one considers that at the height of the campaign approximately 1.15 million litres of water per day had to be provided for human and animal consumption. It was indeed water and securing access to this crucial resource, that remains one of

81. DOD Archives, DC, Group 2, Box 668, File 848/9199, Poisoned Water in GSWA, "Correspondence between Acting Director Medical Services and Secretary for Defence re Infection of Water by Enemy during Hostilities in GSWA", 29 September 1915. 
Kleynhans - The impact of water on the South African Campaign in German South West Africa

the defining aspects of the South African campaign in South West Africa during the First World War.

\section{REFERENCES}

Black, J., Rethinking Military History (Routledge, London, 2004).

Bley, H., South-West Africa under German Rule, 1894-1914 (Heinemann Educational Books, London, 1971).

British Foreign Office, German African Possessions, Volume 18, No. 112: South West Africa (H.M. Stationary Office, London, 1920).

Bruwer, J.P. van S., South-West Africa: The Disputed Land (Nasionale Boekhandel, Port Elizabeth, 1966).

Clonts, D.R., “A Dilemma of War: Decisive Force vs Fabian Strategy”, MA dissertation, University of Denver, 1999.

Collyer, J.J., The Campaign in German South West Africa, 1914-1915 (Government Printer, Pretoria, 1937).

Corson, M.W., “Operation Iraqi Freedom: Geographical Considerations for Desert Warfare”, in E.J. Palka and F.A. Galgano (eds), Military Geography: From Peace to War (McGraw-Hill, Boston, 2005), pp 155-186.

Couzens, T., The Great Silence: From Mushroom Valley to Delville Wood, South African Forces in World War One (Sunday Times Books, Johannesburg, 2014).

Cruise, A., Louis Botha's War: The Campaign in German South-West Africa, 1914-1915 (Penguin, Johannesburg, 2015).

Delport, A., “'Boks and Bullets, Coffins and Crutches': An Exploration of the Body, Mind and Places of 'Springbok' South African Soldiers in the First World War", MA dissertation, Stellenbosch University, 2015.

Garcia, A., "Manoeuvre Warfare in the South African Campaign in German South West Africa during the First World War", MA dissertation, University of South Africa, 2015.

General Staff, The Union of South African and the Great War 1914-1918: Official History (Government Printer, Pretoria, 1924).

Gleeson, I., The Unknown Force: Black, Indian and Coloured Soldiers through Two World Wars (Ashanti Publishing, Rivonia, 1994).

Grundlingh, A.M., Fighting their Own War: South African Blacks and the First World War (Ravan Press, Johannesburg, 1988).

Herrfurth, K., Fürst Bismarck und die Kolonialpolitik (E. Trewendt's Nachfolger, Berlin, 1909). 
Kleynhans - The impact of water on the South African Campaign in German South West Africa

Jacobs, J.A., Janse van Rensburg, H.S. and Smit, H.A.P., "Military Geography in South Africa at the Dawn of the 21st Century", South African Geographical Journal, 84, 2 (2002), pp 195-198.

Kleynhans, E.P., "South African Invasion of German South West Africa (Union of South Africa), 1914-1918, in International Encyclopedia of the First World War (Freie Universität, Berlin, 2015) available online at http://encyclopedia.1914-1918online.net/regions/Southern Africa).

L'Ange, G., Urgent Imperial Service: South African Forces in German South West Africa 1914-1915 (Ashanti Publishing, Rivonia, 1991).

Lehmann, P.N., "Between Waterberg and Sandveld: An Environmental Perspective on the German-Herero War of 1904", in German History, 32, 4 (2014), pp 533558.

Nasson, B., Springboks on the Somme: South Africa and the Great War, 1914-1918 (Penguin Books, Johannesburg, 2007).

Nasson, B., WW1 and the People of South Africa (Tafelberg, Cape Town, 2014).

Ottweiler, E., "Die Niederschlagsverhältnisse von Deutsch-Südwestafrika”, MA dissertation, Münster University, 1906.

Pakenham, T., The Scramble for Africa, 1876-1912 (Abacus, London, 2012).

Rayner, W.S. and O'Shaughnessy, W.W., How Botha and Smuts Conquered South West Africa (Simpkin, London, 1916).

Rhebock, T., Deutsch-Südwest-Afrika (Dietrich Reimer, Berlin, 1898).

Rhebock, T., Deutschlands Pflichten in Deutsch-Südwestafrika (Dietrich Reimer, Berlin, 1904).

Sampson, A., World War I in Africa: The Forgotten Conflict among the European Powers (I.B. Taurus, London, 2013).

Smit, H.A.P. and Janse van Rensburg, H.S., "Success and Failure along the Modder River during the Anglo-Boer War: The Influence of Terrain", Scientia Militaria, 42, 4 (2014), pp 117-142.

Stejskal, J., The Horns of the Beast: The Swakop River Campaign and World War I in South-West Africa, 1914-15 (Helion \& Co, Solihull, 2014).

Stern, C. and Lau, B., Namibian Water Resources and their Management: A Preliminary History (National Archives of Namibia, Windhoek, 1990).

Strachan, H., The First World War in Africa (Oxford University Press, New York, 2007).

Trew, H.F., Botha Treks (Blackie \& Son, Glasgow, 1936).

Union Office of Census and Statistics, Official Yearbook of the Union and of Basutoland, Bechuanaland Protectorate and Swaziland, No. 5, 1922 (Government Printer, Pretoria, 1923). 
Van der Waag, I.J., "Water and Ecology of Warfare in Southern Africa", in J.W.N. Tempelhoff (ed.), African Water Histories: Transdisciplinary Discourses (NorthWest University, Vanderbijlpark, 2005), pp 117-132.

Van der Waag, I.J., "The Battle of Sandfontein, 26 September 1914: South African Military Reform and the German South-West Africa Campaign, 1914-1915", First World War Studies, 4, 2 (2013), pp 141-165.

Van der Waag, I.J., A Military History of Modern South Africa (Jonathan Ball, Cape Town, 2015).

Walker, H.F.B., A Doctor's Diary in Damaraland (Edward Arnold, London, 1917).

Warwick, R.C., "Reconsideration of the Battle of Sandfontein: The First Phase of the German South West Africa Campaign, August to September 1914", MA dissertation, University of Cape Town, 2003.

Warwick, R.C., "The Battle of Sandfontein: The Role and Legacy of Major General Sir Henry Timson Lukin", Scientia Militaria, 34, 2 (2006), pp 65-92.

Williams, D., Springboks, Troepies and Cadres: Stories of the South African Army, 19122012 (Tafelberg, Cape Town, 2012).

Winters, H.A., et al, Battling the Elements: Weather and Terrain in the Conduct of War (Johns Hopkins University Press, Maryland, 1998).

Whitmore, F.C., "Terrain Intelligence and Current Military Concepts", American Journal of Science (Bradley Volume), 258A (1960). 